\title{
ATTITUDES OF PRE-SERVICE TEACHERS IN PRIMARY AND PRE-SCHOOL PEDAGOGY TO WORK IN THEIR SPECIAL SUBJECT \\ Veselina Ivanova ${ }^{1}$, Eleonora Mileva ${ }^{2}$
}

\begin{abstract}
The purpose of the study was to examine the attitudes of pre-service teachers in primary and pre-school pedagogy to work in their subject. 76 pre-service teachers in primary and pre-school pedagogy on the Bachelor's degree from Trakia University in Stara Zagora participated in the research. Half of the respondents had professional experience at primary schools or kindergartens. A special questionnaire was applied, related to the attitudes of the future teachers. The statistical method used for the research was alternative analysis.

Factors influencing the professional realization and career development of the future teachers in the conditions of the dynamically reforming education in Bulgaria were presented. The pre-service teachers in primary and pre-school pedagogy were willing to continue their qualification and education. The future teachers would like to work in their special subject and would not change the profession. Different motives for professional realization of future teachers were established.
\end{abstract}

UDC Classification: 378, DOI: https://doi.org/10.12955/pss.v1.56

Keywords: attitudes, pre-service teachers, profession, interests, primary and pre-school pedagogy

\section{Introduction}

The motivation of pre-service teachers for choosing a teaching profession and the expectations of future primary and pre-school teachers for the profession significantly affect their work and professional development. In recent years in Bulgaria there has been considerable interest in professional activities at school.

The changed socio-economic situation in the country reflects the higher interest of young people in the teaching profession related to increasing teachers' salaries and providing more opportunities for qualification of educators (Mileva, 2018; Ivanova \& Mileva, 2019).

The adoption of a number of normative documents regulating the improvement of teachers' professional qualification helped to increase the status of teachers in the society (Law for Pre-school and School Education, 2016; Regulation № 15 for the status and professional development of teachers, principals and other pedagogical specialists, 2019; Regulation for Inclusive Education, 2017).

In the specialized literature the attitudes of students to their future professional activity was of considerable interest. Research was being conducted to determine the interest and the attitudes of students from different pedagogical faculties in the country towards their profession.

Due to its specific characteristics, the teaching profession has always been the focus of public attention, and the teacher has traditionally been charged with very high expectations and responsibilities.

It was necessary to underline the specific characteristics of the teacher's profession, determining the significance of the pedagogical profession, and the meaning attached to the concept of "teacher's professionalism" (Doncheva, 2016).

The current quality of education in Bulgaria corresponds to the qualifications of teachers. The state educational standard for the status and professional development of pedagogical specialists has created prerequisites for enhancing the authority and social status of teachers, for professional and career development (Kyurkchiyska, 2019).

Babakova (2019) presented a scale for measuring the factors that influenced the choice of the teaching profession. In this relation students in pedagogical specialties were surveyed and motivational characteristics which led to their choice of the teaching profession were presented.

Chernev \& Zahariev (2002) placed an accent on the students' motivation in the educational process. The authors underlined the main motives for participation in the physical education lessons.

Penkova \& Legurska (2019) conducted a questionnaire survey of expectations for a "supportive environment" among practitioners up to the age of 35. The expectations and attitudes of young people to the teaching profession were examined. Data on attitudes to the teaching profession were presented,

\footnotetext{
${ }^{1}$ Veselina Ivanova, Faculty of Education, Trakia University, Stara Zagora, Bulgaria, v_g_chipeva@abv.bg

${ }^{2}$ Eleonora Mileva, National Sports Academy "Vassil Levski”, Sofia, Bulgaria, emileva2002@gmail.com
} 
as well as the difficulties that teachers encountered in their teaching practice (Penkova \& Legurska, 2019).

A study on the attitudes of undergraduate and master's students in the specialty "Pre-primary and primary school pedagogy" towards inclusive education as an integral part of the right to education revealed, that undergraduate students "specify the acceptance and respect of individual needs and implementation of differentiated pedagogical approaches as the most important principle, second comes the principle of non-discrimination and reduction of the influence of social inequalities" (Petrova \& Valchev, 2018). The results also showed that master's students highly appreciated the principle of cooperation and teamwork among all participants in the process of inclusive education (Petrova \& Valchev, 2018). These results were indicative of already formed social and professional attitudes with reference to inclusive education, addressed to children with special educational needs.

The analysis of the curricula of the Faculties of Pedagogy in Bulgaria showed that the future preschool and primary school teachers did not receive appropriate training to work with children with special educational needs. On this basis a concept for inclusive training programs and additional qualification of future teachers was created (Terzieva, 2019).

Georgieva (2019) presented the results of an empirical study of teachers' professional and personal readiness to work for the social adaptation and development of children with Down's syndrome. 112 teachers from kindergartens and state schools in Bulgaria participated in the research. The obtained data illustrated the increase of the professional capacity of pre-school and primary school teachers in terms of their active participation in the social-adaptive work with children in the considered category, and in the teachers' greater sensitivity to the problem (Georgieva, 2019).

Attitudes of teachers to their future work have influenced the quality of the learning process and the achievement of good results in the educational sphere. We assume that the pre-service teachers in primary and pre-school pedagogy at Trakia University have positive attitudes to the professional work and want to work as teachers in primary schools and kindergartens.

\section{Methodology}

The purpose of the study was to examine teachers' attitudes of pre-service teachers in primary and preschool pedagogy to work in their special professional subject. A total of 76 pre-service teachers with a Bachelor's degree in the specialty Pre-school and Primary School Pedagogy, participated in the research.

It has to be underlined that 75 (98.7\%) of all students were female and only 1 (1.3\%) was male. Feminization of the teaching profession is very strong in this area of pedagogy.

The surveyed teachers were of different ages. Most of the respondents were at the age between 31 and 45 years old $-60.5 \%$. The second group was up to 30 years old $-36.8 \%$ and only $2.6 \%$ were over 45 . Half of the surveyed persons (50\%) had an internship in elementary school or kindergarten.

At the time of the survey, it was found that $53.9 \%$ of the trainees did not work as teachers. At the same time, $34.2 \%$ worked in kindergartens, and the remaining $11.9 \%$ worked in the primary school level. It was interesting to note, that $31(88.6 \%)$ of the primary and pre-school teacher trainees, worked in small towns or villages and only $4(11.4 \%)$ worked in the capital or large cities.

Another interesting fact is that $57.9 \%$ of the pre-service teachers have completed vocational high schools, $30.3 \%$ have completed schools specialized in languages, liberal arts or natural sciences, and $6.6 \%$ have graduated from sports or arts schools. The remaining 5.2\% have graduated from other types of secondary schools.

A special questionnaire was created and applied, with criteria related to the attitudes of the Bachelor's students to the teaching profession. The items were focused on different dimensions of the students' attitudes. The statistical method used for the research was alternative analysis.

\section{Results and Discussion}

The results to the question whether students intend to continue their education in the next educational degree and/or to take qualification courses after completing their specialization, revealed a very good trend. $85.5 \%$ of the respondents answered positively and only $3.9 \%$ answered negatively. There was also a group that could not decide at the moment $-10.6 \%$. 
The respondents' intentions to work as primary or pre-primary teachers were very clear, with $89.5 \%$ responding positively and only $1.3 \%$ responding negatively. The relative share of future teachers who could not specify their intentions was low $-9.2 \%$. This means that the students in the survey were aware of their future professional development, and that their education in the pedagogical specialty at the university was planned and purposeful. This is in line with our previous research, which focused on the motivation and desire for professional activity of future teachers (Mileva, 2002).

The stressful nature of the teaching profession was cited as the main reason for the hesitation and the negative response. The amount of stress among teachers has been announced as a serious problem affecting their health and work capacity by Valkov (2017). The author outlined some behavioral and psychological coping strategies to deal with the tension in the teaching profession (Valkov, 2017).

Teachers are among the risky occupational groups (Cooper et al., 2005), most commonly affected by the emotional burnout syndrome (Kostova, 2014). Teachers' occupational stress is related to workload: lesson planning, organizing activities, coping with classroom discipline and 'problem' students, lack of interest and low student achievement (Antoniou et al., 2006). According to the same study, female teachers experience higher levels of occupational stress related to interaction with students, colleagues, workload, student achievement and emotional exhaustion.

As a whole, the future teachers considered that the conditions in Bulgaria were favorable for work in the specialty - $18.4 \%$ to a large extent, and $63.2 \%$ to a certain extent. The relative share of the surveyed persons, who believed that the conditions for practicing the teaching profession in the country are not good $-3.9 \%$, was very low. These results are likely to be related to new regulations and legislative initiatives taken by the state over the last five years.

The proportion of the surveyed pre-service teachers who would seek employment abroad was small.

A very positive fact was that the proportion of students who said they would not change their profession of pre-primary and primary teachers was significantly higher - 65.8\%. However, some of the surveyed persons hesitate or cannot judge when answering the question - a total of $27.6 \%$ (Figure 1).

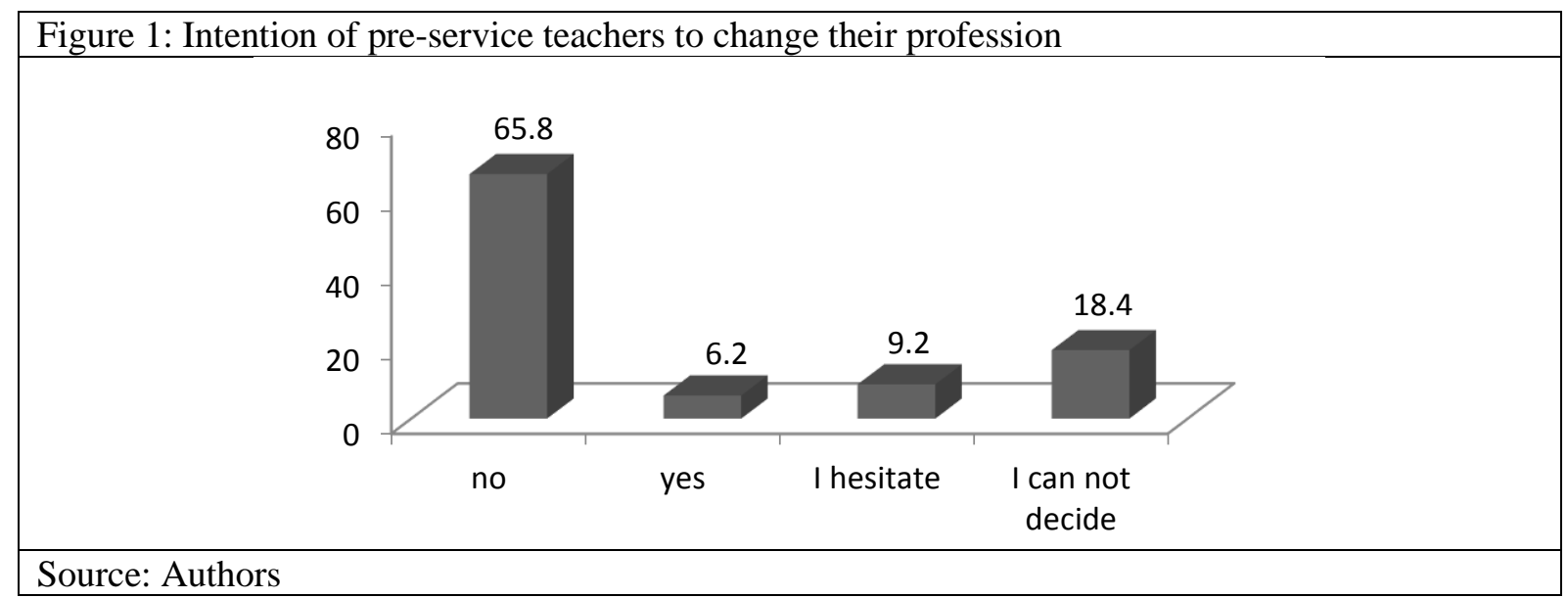

Figure 2: Evaluation of the status of the teacher's profession in Bulgaria

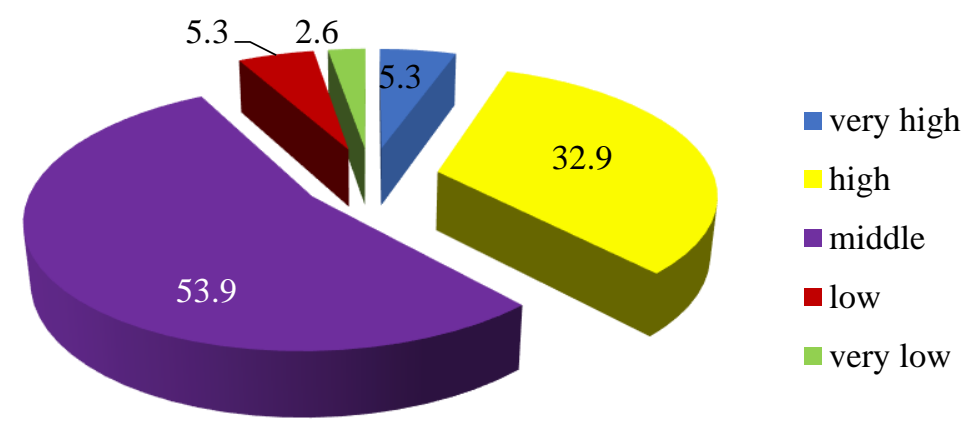

Source: Authors 
The answers about the prestige of the teacher's profession in Bulgaria were varied. More than half of the surveyed people rated the prestige of the profession with an average degree of significance - 53.9\% (Figure 2). The prestige of Bulgarian teachers was rated as high and very high by $38.2 \%$. The smallest group of surveyed students believed that the pedagogical profession is low and very low $-7.9 \%$.

The significant changes in the educational field and the adoption of a number of important normative documents in the country, aimed at the permanent qualification and certification of pedagogical staff, also influenced the opinion of future teachers. $84.2 \%$ considered the opportunities for upgrading the qualification and professional development of primary and pre-school teachers in Bulgaria as very favorable and favorable. Only $15.8 \%$ considered them satisfactory.

At the same time, students were very critical to the ongoing reforms in the field of education in the country. The opinions here were quite opposite. Half of those surveyed approved of these reforms $52.6 \%$ and the other half disapproved $-43.4 \%$. There was also a group that had no opinion on the issue - 3.9\%. The main reason for the different opinions was probably the lack of information about the changes in the educational system in the country, as well as, the lack of contacts with the institutions that carried out the educational policy in Bulgaria.

Interesting for the research were the motives of future teachers to work in their special subject (Table 1). The first motive was the love for children and the desire to work with children. Secondly, the favorable working environment and good material working conditions were indicated. The third major motive was the high prestige of the teaching profession and its social stability. Next came the freedom to structure educational content and to use innovative approaches.

\begin{tabular}{|c|l|c|}
\hline \multicolumn{2}{|c|}{ Table 1: Motives for professional activity of future teachers } \\
\hline \multicolumn{1}{|c|}{ Motives } & $\%$ \\
\hline 1 & the love for children and the desire to work with children & 42.1 \\
\hline 2 & the favorable working environment and good material working conditions & 21.0 \\
\hline 3 & the prestige of the teaching profession and its social stability & 14.5 \\
\hline 4 & the possibility for professional development & 5.3 \\
\hline 5 & the freedom to structure educational content and took innovative approaches & 6.6 \\
\hline 6 & the good interactions with colleagues & 3.9 \\
\hline 7 & the good interactions and relationships with parents & 2.0 \\
\hline 8 & the high self-esteem based on good academic background & 2.6 \\
\hline 8 & other motives & 3.0 \\
\hline$S$
\end{tabular}

Source: Authors

The following motives for the teaching profession should also be noted: the professional development opportunities in the country and abroad, and the acquisition of various educational and qualification degrees and retraining, the good professional relations with colleagues, the good interactions and relationships with parents, the high self-esteem based on good academic background, etc.

It was clear that the professional motives were diverse. However, there was a desire to work with children and the idea that future teachers would be useful for the development of pupils in pre-school and primary school age.

The answers to the question about the main problems of primary and pre-school teachers in Bulgaria were very different. The first problem - the large number of children in the groups in kindergarten or in the classes at school, not allowing qualitative and effective work, was the one with the highest relative share $-27.6 \%$.

Second in importance came the problem about the great amount of administrative duties and the overload of teachers with excess paperwork - $21 \%$.

Another problem was the lack of respect for the teacher by students and parents - 19.7\%. Other major problems were the high responsibility placed on teachers - $13.2 \%$, poor interaction with parents $10.5 \%$, poor facilities in small towns $-4 \%$, and others.

\section{Conclusions}

From the conducted research on the attitudes of the pre-service teachers in primary and pre-school pedagogy towards the profession and the analysis of the results it can be concluded that the pre-service teachers are willing to continue their education and qualification in the next educational degree and to participate in different qualification courses. At the same time the respondents would like to work as 
primary and pre-school teachers in the future. An interesting fact is that the future teachers would not change their pedagogical profession. The opportunities for better qualification and professional development in the country are considered as favorable by the studied pre-service teachers.

The results from the study give a clear picture of the factors influencing the professional attitudes and orientation of the surveyed pre-service teachers and outline the benchmarks for improving career development opportunities.

\section{References}

Antoniou, A., Polychroni, F. \& Vlachakis, A. (2006). Gender and age differences in occupational stress and professional burnout between primary and high-school teachers in Greece, Journal of Managerial Psychology, 21 (7), 682-690, doi.org/10.1108/02683940610690213

Babakova, L. (2019). Motivaziyata na studentite pri izbora na uchitelskata profesiya. [Students' motivation in choosing the teaching profession]. Strategies for Policy in Science and Education, 27 (5), 520-539.

Chernev, V. \& Zahariev, I. (2002). Motivaziyata na uchenizite ot V do VIII klas za uchastieto im v urozite po fizichesko vaspitanie. [Motivation of students from V to VIII class for participation in physical education lessons]. Sport \& Science, extra issue, 72-79.

Cooper, J.S., Cartwright, C., Donald, S., Taylor, I. \& Millet, C. (2005). The experience of work related stress across occupations. Journal of Managerial Psychology, 20 (2), 178-87

Doncheva, Y. (2016). Kommunikativnaya kompetenciya uchitelya kak osnovopolagajshtaya ego profesionalizma [Communicative competence of the teacher as the fundamental obtaining of its professionalism]. Professionalnoe obrazovanie I tehnologicheskoe obuchenie v RF $i$ za rubezom. Novokuzneck: NFI KemGU, 1, 96-104.

Georgieva, D. (2019). Profesionalno-lichnostnata gotovnost na uchitelite kato sozialno-psihologicheski resurs za formirane na sozialnata adaptaziya pri deza sas sindrpm na Daun. [Professional-personal readiness of the teachers as socialpsychological resource for development of social adaptation of children with Down syndrome]. Pedagogy, 91 (5), 626-641.

Ivanova, V. \& Mileva, E. (2019). Teachers' satisfaction with their professional activities in physical education and sport. In P. Hájek, \& O. Vít (Ed.), Vol 7 (2019): CBU International Conference Proceedings 2019: CBU Research Institute. https://doi.org/10.12955/cbup.v7.1400,_453-458.

Kostova, N. (2014). Iztochnitsi na stres i vliyanieto im varhu udovletvorenostta ot truda pri uchiteli po fizichesko vazpitanie i sport [Stress sources and their influence on work satisfaction with physical education and sports teachers]. Savremenni tendenzii na fizicheskoto vaspitanie i sporta. Sofia: SU „St. K1. Ohridski“, 77-84.

Kyurkchiyska, V. (2019). Kvalifikaziyata na uchitelite v konteksta na savremennite predizvikatelstva za kachestveno obrazovanie. [Qualification of teachers in the context of current challenges for quality education]. Strategies for Policy in Science and Education, 27 (6), 607-617.

Law for Pre-school and School Education (2016, August 01). Retrieved from https://www.lex.bg/bg/laws/ldoc/2136641509.

Mileva, E. (2002). Udovletworenost na studentite ot NSA "V. Levski" (II kurs) ot uchebniya prozes i motivaziya za profesionalna deynost. [Satisfaction of students from the National Sports Academy "V. Levski" (II study year) with the educational process and motivation for professional activity]. Sport, Society, Education, Vol. 7, Sofia, NSA PRESS, 44-49.

Mileva, E. (2018). Profesionalna podgotovka po fizichesko vazpitanie i sport na uchitelite v nachalniya etap na osnovnata obrazovatelna stepen. [Professional preparation in physical education and sport of primary teachers]. Sport, \& Science, 62, (4), 106-114.

Penkova, R. \& Legurska, M. (2019). Anketno prouchvane na ochakvaniyata za "podkrepyasta sreda" sred praktikuvastite pedagozi do 35-godishna vazrast. [Survey of expectations for a "supportive environment" among practitioners under 35]. Strategies for Policy in Science and Education, 27 (5), 520-539.

Petrova, V. \& Valchev, G. (2018). Prouchvane naglasite na studenti pedagozi kam priobshtavashtoto obrazovanie kato neizmenna chast ot pravoto na obrazovanie. [Examining teacher educators' attitudes towards inclusive education as an integral part of the right to education]. Pedagogy (6), 836-846.

Regulation for Inclusive Education (2017, October 27). Retrieved from https://www.mon.bg

Regulation № 15 for the status and professional development of teachers, principals and other pedagogical specialists (2019, July 22). Retrieved from https://www.mon.bg

Terzieva, G. (2019). A concept for inclusive physical education training program for future pre-school and primary-school teachers. Pedagogy, 91 (5), 696-701.

Valkov, P. (2017). Stress in teaching profession and coping strategies. Educational Forum Online Journal (3). doi: 10.15547/PF.2017.019. 